\title{
Pemanfaatan Analisis Spasial Hot Spot (Getis Ord Gi) untuk Pemetaan Klaster Industri di Pulau Jawa dengan Memanfaatkan Sistem Informasi Geografi
}

\author{
Andri Kurniawan ${ }^{1}$, Mohammad Isnaini Sadali ${ }^{2}$
}

\author{
Afiliasi dan Korespondensi \\ 1,2 Program Studi Pembangunan Wilayah, Departemen Geografi Pembangunan, Fakultas \\ Geografi UGM \\ 1andri.kurniawan@ugm.ac.id., 2 m.isnaini.s@ugm.ac.id.
}

\section{INTISARI}

Perkembangan industri di Indonesi terus mengalami kemajuan yang ditandai dengan semakin banyaknya jumlah industri dan semakin meningkatnya kontribusi bagi pertumbuhan ekonomi. Dalam perkembangannya, banyak industri yang didirikan dan dikembangkan dalam satu kawasan tertentu membentuk klaster agar memiliki keuntungan aglomerasi dan komplementaritas produksi. Klaster-klaster industri di Indonesia mulai menyebar ke berbagai daerah, terutama di Pulau Jawa. Oleh karena itu, diperlukan kajian dinamika pola perkembangan dan pergeseran spasial klaster industri untuk mengidentifikasi dan melakukan pemetaan klaster industri. Pemetaan klaster industri dilakukan dengan dukungan analisis spasial memanfaatkan analisis spasial Hot Spot (Getis Ord $\mathrm{Gi}^{*}$ ) dari Sistem Informasi Geografi.

Tujuan dari penelitian ini adalah: (1) Penentuan Klaster Industri di Pulau Jawa melalui Pemanfaatan Analisis Spasial Hot Spot (Getis Ord Gi*), (2) Melakukan analisis perbandingan pola spasial klaster industri menurut klasifikasi industri, dan (3) Menganalisis pergeseran spasial klaster industri di Pulau Jawa selama 20 tahun terakhir. Penelitian ini menggunakan metode penelitian kuantitatif dengan data sekunder sebagai data utama dan dianalisis secara deskriptif. Hasil penelitian ini utamanya diharapkan mampu melihat pola spasial industri dan klaster industri serta pergeserannya dalam 20 tahun terakhir, sehingga dapat dimanfaatkan oleh para akademisi, praktisi, pemerintah, swasta maupun masyarakat dalam mengembangankan industri.

Kata kunci: industri, klaster, spasial, Getis Ord Gi* 
Pemanfaatan Analisis Spasial Hot Spot (Getis Ord Gi*) untuk Pemetaan Klaster Industri di Pulau Jawa dengan Memanfaatkan Sistem Informasi Geografi.

Kurniawan, A. \& Sadali, M.I.

\section{LATAR BELAKANG}

Perkembangan industri di Indonesi terus mengalami kemajuan yang ditandai dengan semakin banyaknya jumlah industri dan semakin meningkatnya kontribusi bagi pertumbuhan ekonomi. Sektor industri berpotensi memberikan sumbangan yang besar terhadap penyerapan tenaga kerja dan peningkatan devisa sekaligus diharapkan mampu mendorong peningkatan daya saing bangsa. Dalam perkembangannya, banyak industri yang didirikan dan dikembangkan dalam satu kawasan tertentu dengan membentuk klaster industri. Pembentukan klaster industri tersebut didasarkan atas keuntungan aglomerasi dan komplementaritas produksi. Perkembangan klaster-klaster industri di Indonesia secara alami sudah lama terjadi namun secara terstruktur dan ditunjang melalui kebijakan pembangunan mulai berkembang pada awal tahun 2000-an. Pengembangan klaster industri di Indonesia dimaksudkan untuk meningkatkan daya saing sekaligus diharapkan dapat menggerakkan ekonomi lokal.

Konsep pengembangan klaster industri (industrial cluster) pertamakali digagas oleh Porter (1990) dalam bukunya "The Competitive Advantage of Nation" sebagai kebijakan untuk meningkatkan daya saing negara Amerika Serikat. Porter mendefinisikan klaster sebagai kelompok industri yang saling berhubungan dan berdekatan secara geografis dengan institusiinstitusi yang terkait dalam suatu bidang khusus karena kebersamaan dan saling melengkapi. Melalui pengembangan klaster industri diharapkan akan terjadi localization economies yang mendorong adanya konektivitas dan meningkatkan efisiensi ekonomi. Menurut Porter, pendekatan klaster merupakan cara yang paling efektif dan produktif untuk mengorganisir kegiatan ekonomi sehingga dapat meningkatkan daya saing. Strategi pengembangan kawasan berbasis klaster menawarkan cara yang lebih efektif dan efisien dalam mengembangkan dan membangun ekonomi wilayah secara lebih kuat, dan mempercepat pembangunan ekonomi secara keseluruhan. 
Pemanfaatan Analisis Spasial Hot Spot (Getis Ord Gi*) untuk Pemetaan Klaster Industri di Pulau Jawa dengan Memanfaatkan Sistem Informasi Geografi.

Klaster yang terbentuk pada suatu wilayah memungkinkan adanya keterkaitan aktivitas dan mendorong berkembangnya berbagai proses produksi. Keterkaitan yang terjadi dalam klaster memungkinkan adanya pemakaian bersama atas berbagai sarana dan prasarana pendukung sehingga akan lebih efisien dalam penyediaannya. Selain itu, perkembangan klaster industri juga membuka peluang untuk lebih mengembangkan potensi lokal dan meningkatkan skala produksi. Oleh karena itu, perkembangan klaster industri pada suatu wilayah mencerminkan pula adanya penguatan ekonomi .

Kendati pakar ekonomi regional dan pakar ilmu geografi sudah sejak lama mengamati fenomena ketimpangan distribusi aktifitas industri manufaktur secara spasial, baru sedikit studi yang meneliti tentang konsentrasi spasial di Negara Sedang Berkembang (NSB). Kasus Indonesia menawarkan "laboratorium" yang amat bagus dan menarik untuk mempelajari pola konsentrasi spasial di NSB. Pola spasial pembangunan industri di Indonesia menunjukkan ketimpangan distribusi secara geografis (Kuncoro, 2002).

Pada kerkembangannya, klaster-klaster industri di Indonesia mulai menyebar ke berbagai daerah, terutama di Pulau Jawa. Perkembangan klaster industri di daerah banyak dipengaruhi oleh keberadaan bahan baku, dukungan fasilitas, dan ketersediaan lahan disamping didukung oleh kebijakan daerah. Peningkatan klaster-klaster industri sejalan dengan semakin berkembangnya jumlah dan jenis indutri di daerah terutama indutri kecil dan menengah (IKM). Dengan semakin berkembangnya klasterklaster industri di daerah menunjukkan secara spasial telah terjadi penyebaran. Penyebaran klaster-klaster industri tersebut menarik untuk dikaji dalam upaya melihat dinamika pola perkembangan dan pergeseran spasial yang terjadi.

Selanjutnya, untuk mengkaji dinamika pola perkembangan dan pergeseran spasial klaster industri diperlukan adanya upaya untuk mengidentifikasi dan melakukan pemetaan klaster industri. Untuk dapat 
melakukan pemetaan klaster industri diperlukan dukungan analisis spasial dengan bantuan Sistem Informasi Geografi (SIG). Melalui pemanfaatan Sistem Informasi Geografi (SIG) dapat dilakukan pemetaan klaster industri dengan memanfaatkan analisis spasial Hot Spot (Getis Ord Gi*). Hot Spot Analisis adalah metode deteksi klaster dalam SIG yang dapat mengidentifikasi konsentrasi spasial yang signifikan secara statistik dari nilai-nilai tinggi maupun nilai-nilai yang rendah terkait dengan seperangkat fitur geografis. Pemanfaatan analisis spasial Hot Spot (Getis Ord Gi*) dapat digunakan untuk menentukan klaster industri dengan dasar intensitas dan kedekatan lokasi.

\section{TUJUAN PENELITIAN}

Berdasarkan latar belakang di atas, kajian ini ditujukan untuk:

1. Penentuan Klaster Industri di Pulau Jawa melalui Pemanfaatan Analisis Spasial Hot Spot (Getis Ord Gi*).

2. Melakukan analisis perbandingan pola spasial klaster industri menurut klasifikasi industri.

3. Menganalisis pergeseran spasial klaster industri di Pulau Jawa selama 20 tahun terakhir.

\section{TINJAUAN PUSTAKA}

\subsection{Konsep Klaster}

Pengertian klaster (cluster) secara harfiah sebagai kumpulan, kelompok, himpunan, atau gabungan obyek tertentu yang memiliki keserupaan atau atas dasar karakteristik tertentu. Namun demikian, dalam konteks industri, klaster industri (industrial cluster) merupakan terminologi yang mempunyai pengertian khusus. Dalam banyak literatur, pengertian klaster industri mempunyai makna yang beragam. Departemen Perindustrian Republik Indonesia (2005) mendefinisikan klaster industri sebagai kelompok industri dengan focal/core industry yang saling berhubungan secara intensif dan membentuk partnership, baik dengan supporting industry maupun related industry. Definisi tersebut agak berbeda 
dengan pendapat Munnich Jr., et al. (1999) yang memberikan gambaran klaster industri sebgai konsentrasi geografis dari perusahaan dan industri yang saling berkompetisi, komplementer, atau saling terkait, yang melakukan bisnis satu dengan lainnya dan/atau memiliki kebutuhan serupa akan kemampuan, teknologi dan infrastruktur.

Lain halnya dengan Porter (1990) yang mendefinisikan klaster industri sebagai sekumpulan perusahaan dan lembaga-lembaga terkait di bidang tertentu yang berdekatan secara geografis dan saling terkait karena "kebersamaan (commonalities) dan komplementaritas". Definisi klaster industri lebih lanjut juga dijelaskan Taufik (2008) yang memberikan pengertian klaster industri sebagai kelompok industri spesifik yang dihubungkan oleh jaringan mata rantai proses penciptaan/peningkatan nilai tambah. Kelompok industri spesifik tersebut merupakan jaringan dari sehimpunan industri yang saling terkait (biasanya disebut dengan industri inti/core industries - yang menjadi "fokus perhatian," industri pendukungnya/supporting industries, dan industri terkait/related industries), pihak/lembaga yang menghasilkan pengetahuan/ teknologi (termasuk perguruan tinggi dan lembaga penelitian, pengembangan dan rekayasa/litbangyasa), institusi yang berperan menjembatani/bridging institutions (misalnya broker dan konsultan), serta pembeli, yang dihubungkan satu dengan lainnya dalam rantai proses peningkatan nilai (value adding production chain). Dalam pengertian ini, industri inti, pendukung, atau terkait sebenarnya sama pentingnya. Istilah tersebut lebih menunjukkan "peran" setiap industri - bukan menunjukkan yang satu lebih penting dari yang lain. Gambaran model generik dari klaster industri dapat dilihat pada Gambar 1. 


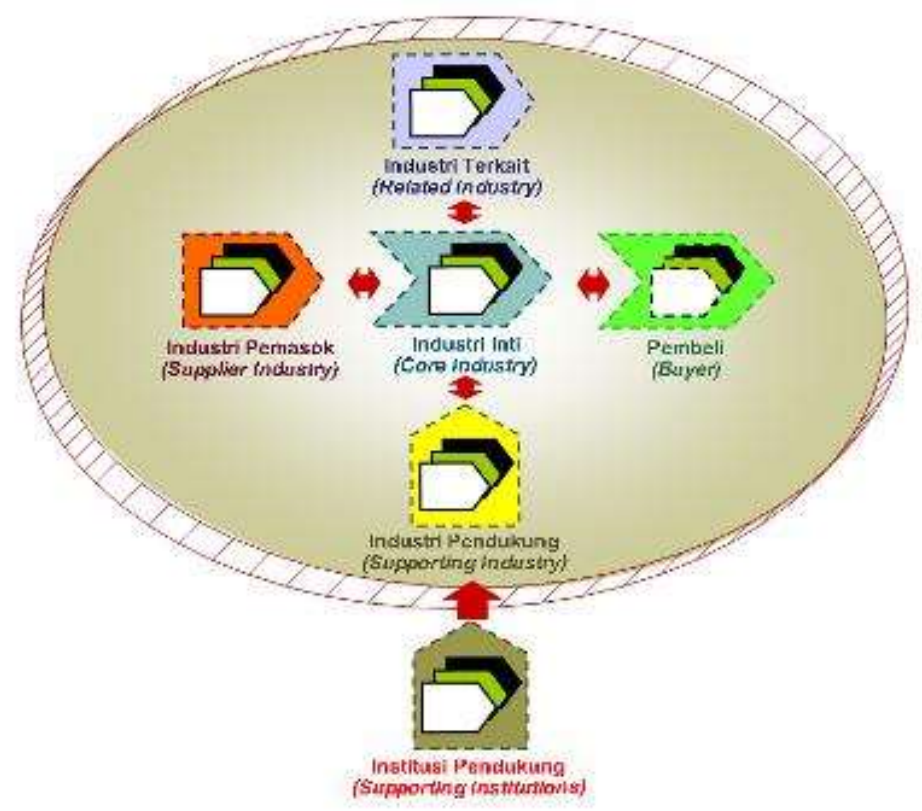

Model Generik Klaster Industri

Gambar 1. Model Generik Klaster Industri

Sumber: Asosiasi Klaster Indonesia (AKsI), 2014

Kementerian Koperasi dan UKM dalam buku "Pemberdayaan UKM Melalui Pemberdayaan SDM dan Klaster Bisnis" menunjukkan pengertian klaster sebagai kelompok kegiatan yang terdiri atas industri inti, industri terkait, industri penunjang, dan kegiatan-kegiatan ekonomi (sektor-sektor) penunjang dan terkait lain, yang dalam kegiatannya akan saling terkait dan saling mendukung. Lingkup geografis klaster dapat sangat bervariasi, terentang dari satu desa saja atau salah satu jalan di daerah perkotaan sampai mencakup sebuah kecamatan, kabupaten/kota, atau provinsi.

Dari berbagai definisi dan pengertian di atas, selanjutnya Lyon dan Atherton (dalam Taufik. 2008) berpendapat bahwa terdapat tiga hal mendasar yang dicirikan oleh klaster industri, terlepas dari perbedaan struktur, ukuran ataupun sektornya, yaitu:

1. Komonalitas/Keserupaan/Kebersamaan/Kesatuan (Commonality); yaitu bahwa bisnis-bisnis beroperasi dalam bidang-bidang "serupa" atau terkait satu dengan lainnya dengan fokus pasar bersama atau suatu rentang aktivitas bersama. 
Pemanfaatan Analisis Spasial Hot Spot (Getis Ord Gi*) untuk Pemetaan Klaster Industri di Pulau Jawa dengan Memanfaatkan Sistem Informasi Geografi.

2. Konsentrasi (Concentration); yaitu bahwa terdapat pengelompokan bisnis-bisnis yang dapat dan benar-benar melakukan interaksi.

3. Konektivitas (Connectivity); yaitu bahwa terdapat organisasi yang saling terkait/ bergantung (interconnected/linked/interdependent organizations) dengan beragam jenis hubungan yang berbeda.

Dalam sejarah perkembangan indutri, pendekatan pengembangan klaster telah berkembang pesat dalam dua dekade belakangan ini sejak Tahun 1990-an. Pengembangan industri dengan model klaster dipopulerkan secara luas oleh Michael Porter, yang diikuti oleh ahli-ahli yang lain dalam skala global. Porter menyebutkan bahwa konsep pembangunan klaster adalah merupakan cara berpikir baru tentang pembangunan ekonomi, nasional, wilayah, dan lokal. Konsep ini mendorong reposisi peran unit usaha, pemerintah, serta institusi lain penunjang ekonomi untuk meningkatkan kemampuan berkompetisi (Porter, 2000). Pendekatan model klaster dari Porter merupakan pengembangan dari industrial district atau kawasan industri yang dikembangkan oleh Alfred Marshall pada 1920 (Desrochers dan Sautet, 2004). Berbeda dengan model kawasan industri dari Marshall yang hanya fokus pada perusahaanperusahaan sejenis saja, klaster industri model Porter tidak membatasi hanya pada satu jenis industri, namun lebih luas lagi melalui keterlibatan jenis industri lain. Model klaster Porter ini dinamakan Diamond Cluster Model. Pengembangan Diamond Cluster Model ini melibatkan meliputi industri-industri terkait, serta perusahaan-perusahaan lain yang mempunyai keterkaitan dalam teknologi, input yang sama. Dengan bekerja sama dalam satu klaster, maka perusahaan/industri terkait akan memperoleh manfaat sinergi dan efisiensi yang tinggi.Menurut Porter, klaster industri dapat terbentuk pada kota, kawasan regional,bahkan negara.

Pendekatan ini menarik tidak hanya bagi pengembang konsep dan ilmu pengetahuan, namun yang paling besar mendapat manfaat adalah para pelaku usaha, serta pemerintah yang mengelola pembangunan. Selama dua dekade terakhir, konsep klaster industri telah banyak mengundang perhatian berbagai stakeholders baik akademisi, praktisi, 
Pemanfaatan Analisis Spasial Hot Spot (Getis Ord Gi*) untuk Pemetaan Klaster Industri di Pulau Jawa dengan Memanfaatkan Sistem Informasi Geografi.

Kurniawan, A. \& Sadali, M.I.

politisi, birokrat, para ahli ekonomi serta semua pihak yang concern terhadap pengembangan ekonomi lokal suatu wilayah. Pengertian kluster industri hingga saat ini masih debatable disebabkan terdiri dari bermacammacam konsep dan metode pendekatan yang digunakan (David, 2004). Klaster industri merupakan konsep multidimensi yang didasarkan atas sejumlah teori-teori ekonomi dan diukur menggunakan metodologi pendekatan yang berbeda-beda. Namun demikian, secara teoritis konsep klaster industri dibangun oleh teori ekonomi terutama sekali oleh teori ekonomi eksternal dan aglomerasi (Fujita dan Thisse, 1986).

Fenomena perkembangan klaster industri di Indonesia sebenarnya sudah lama terjadi secara alamiah dari kekuatan pasar, namun pengembangan klaster usaha secara sistematis formal di Indonesia baru mulai berkembang sejak awal dekade 2000-an seiring dengan usaha pemulihan perekonomian paska krisis ekonomi tahun 1997. Namun demikian, meskipun kebijakan pengembangan klaster dari Pemerintah sebagiamana tersebut diatas telah memunculkan kegiatan-kegiatan pengembangan klaster di daerah, namun umumnya klaster muncul secara spontan, karena disimulasi oleh berlimpahnya bahan mentah dan tenaga kerja terampil (Weijland, 1999). Berdasarakan penelitian JICA (2004), penyebaran klaster terbesar berada di Jawa-Bali (46,5\%), diikuti Sumatera (18,5\%), Sulawesi (11,3\%), Indonesia bagian Timur (11,3\%) dan Kalimantan (8,7\%). Dari Jawa Bali tersebut penyebaran klaster tertinggi berada di Jawa Tengah. Kebanyakan klaster berlokai di Provinsi Jawa Tengah.

\subsection{Hot Spot Analysis (Getis-Ord Gi*)}

Dalam kajian geografi, sangat diperlukan adanya dukungan analisis statistik terutama berkaitan dengan kajian korelasi spasial. Salah satu yang dapat digunakan untuk mengkaji korelasi spasial yang kemudian ditujukan untuk mengindetifikasi terbentuknya klaster-klaster spasial adalah Hot Spot Analysis. Hot Spot Analysis adalah metode deteksi klaster spasial yang mengidentifikasi konsentrasi spasial yang signifikan secara statistik dari 
nilai-nilai tinggi dan nilai- nilai yang rendah terkait dengan seperangkat fitur geografis (Getis \& Ord, 1992). The Hot Spot Analisis merupakan alat menghitung Getis-Ord Gi* Statistik untuk setiap fitur dalam dataset. Z-score dan $p$-value yang dihasilkan memberikan gambaran di mana klaster spasial fitur nilai-nilai tinggi atau nilai-nilai rendah. Alat ini bekerja dengan melihat setiap fitur dalam konteks fitur tetangga. Sebuah fitur dengan nilai tinggi menarik tetapi mungkin tidak menjadi Hot Spot yang signifikan secara statistik. Untuk menjadi Hot Spot yang signifikan secara statistik, fitur akan memiliki nilai yang tinggi dan dikelilingi oleh fitur-fitur lainnya dengan nilainilai yang tinggi juga. Untuk Z-score nilai positif, semakin besar Z-score positif semakin intens pengelompokannya sehingga membentuk Hot Spot. Untuk Z-score negatif, semakin kecil Z-score negatif semakin intens pengelompokannya sehingga Cold Spot. Hot Spot Analysis (Getis-Ord Gi*) terdapat dalam Mapping Clusters Toolset untuk mengidentifikasi secara lokal klaster spasial nilai-nilai tinggi (hot spots) dan nilai-nilai rendah (cold spots) yang signifikan secara statistik (ESRI, 2010). Adapun formulasi yang digunakan untuk nilai Getis Ord Gi* sebagai berikut.

Rumus 1. Nilai Getis Ord Gi*

$$
\begin{gathered}
G_{i}^{*}=\frac{\sum_{j=1}^{n} w_{i, j} x_{j}-\bar{X} \sum_{j=1}^{n} w_{i, j}}{S \sqrt{\left[\frac{\left[\sum_{j=1}^{n} w_{i, j}^{2}-\left(\sum_{j=1}^{n} w_{i, j}\right)^{2}\right]}{n-1}\right.}} \\
\bar{X}=\frac{\sum_{j=1}^{n} x_{j}}{n} \\
S=\sqrt{\frac{\sum_{j=1}^{n} x_{j}^{2}}{n}-(\bar{X})^{2}}
\end{gathered}
$$

Diketahui : 


$$
\begin{aligned}
\mathrm{Gi}^{*} & =\text { Nilai Getis Ord } \mathrm{Gi}^{*} \\
\mathrm{Xj} & =\text { Nilai/Atribut Fitur } \mathrm{j} \\
\mathrm{Wij} & =\text { Bobot Spasial antara Fitur } \mathrm{i} \text { dan } \mathrm{j} \\
X & =\text { Nilai Rata-Rata } \\
\mathrm{S} & =\text { Standar Deviasi } \\
\mathrm{N} & =\text { Jumlah Fitur }
\end{aligned}
$$

Hot Spot Analysis (Getis-Ord Gi*) mulai banyak digunakan untuk berbagai penelitian. Salah satu penelitian yang dilakukan oleh Kurniawan (2013) memanfaatkan Hot Spot Analysis (Getis-Ord Gi*) untuk mengkaji pola spasial daya dukung wilayah di Daerah Istimewa Yogyakarta (DIY). Salah satu aspek penggunaan analisis Hot Spot adalah untuk mengkaji klaster daya dukung bioekologi. Secara umum dihasilkan 2 (dua) klaster, yaitu spatial cluster of high values (hot spot) dan spatial cluster of low values (cold spot). Klaster yang sangat menonjol terlihat adalah untuk klaster dengan daya dukung biekologi yang rendah (cold spot) yang mempunyai nilai GiZScore kurang dari - 2,58 Std. Dev. Klaster yang terbentuk berada pada Kawasan Perkotaan Yogyakarta dan sekitarnya yang meliputi wilayah bagian selatan Kabupaten Sleman, Kota Yogyakarta, dan wilayah Kabupaten Bantul bagian utara. Kawasan tersebut merupakan Kawasan Aglomerasi Perkotaan Yogyakarta (APY) dan wilayah pinggirannya. Pada kawasan tersebut telah berkembang menjadi kawasan perkotaan yang pesat dengan ditandai adanya perkembangan lahan terbangun dan berkurangnya lahan pertanian serta meningkatnya jumlah penduduk. Kondisi tersebut mencerminkan tingginya tekanan penduduk sehingga daya dukung bioekologinya menjadi rendah. Selain itu terdapat pula klaster daya dukung yang rendah dan agak rendah yaitu di wilayah Perkotaan Wonosari. Terbatasnya biokapaitas dan jumlah penduduk yang tinggi menyebabkan wilayah Perkotaan Wonosari termasuk dalam klaster daya dukung rendah hingga agak rendah.

Kondisi yang berbeda dapat dilihat untuk klaster dengan daya dukung yang tinggi (hot spot). Paling tidak terdapat beberapa klaster hot spot di wilayah DIY. Klaster hot spot yang cukup menonjol adalah di wilayah bagian 
utara Kabupaten Sleman atau pada kawasan lereng Gunung Merapi dan juga di wilayah Perbukitan Menoreh (Perbukitan Denudasional) Kabupaten Kulon Progo. Di dua kawasan tersebut dominasi penggunaan lahannya adalah tanaman tahunan dan lahan pertanian pangan sehingga biokapasitasnya relatif cukup tinggi. Khusus di wilayah Perbukitan Menoreh jumlah penduduknya juga relatif masih terbatas sehingga tekanan penduduknya juga masih rendah. Klaster hot spot juga terdapat pada beberapa lokasi di wilayah pesisir Kabupaten Kulon Progo dan Bantul. Berkembangnya lahan pertanian di kawasan pesisir telah mampu memberikan dukungan terhahap tingginya daya dukung bioekologi. $\mathrm{Di}$ wilayah Perbukitan Baturangung juga terdapat klaster hot spot walauapun tidak terlalu luas. Secara umum gambaran terbentuknya klaster-klaster tersebut memperkuat gambaran distrubusi spasial dari peta sebaran daya dukung bioekologi.

\section{LANDASAN TEORI}

\subsection{Analisis Spasial Hot Spot (Getis Ord Gi*)}

Exploratory Spatial Data Analysis (ESDA) merupakan bagian dari Exploratory Data Analysis (EDA) yang fokus pada pengenalan karakleristik dari data geografis, dan lebih spesifik lagi fokus pada autokorelasi spasial dan heterogenitas spasial (Anselin, 1995). ESDA merupakan sualu kumpulan teknik untuk menggambarkan atau memvisualisasikan distribusi spasial, mengidentifikasi lokasi yang sejenis, menemukan pola asosiasi spasial, klaster atau hot spots dan menduga pola lain dari heterogenitas spasial. Pola asosiasi spasial dalam data geografis secara umum terdiri dari dua metode yaitu metode global dan metode lokal.

Metode Global merupakan analisis pola asosiasi spasial pada skala yang luas untuk melihat distribusi data yang berupa pengelompokan (cluster), terdispersi (dispersed) dan acak (random) dalam suatu keruangan. Metode ini sering disebut sebagai indeks Moran's I dan Getis Ord General Statistic. Luaran yang dihasilkan dengan metode ini adalah 
Pemanfaatan Analisis Spasial Hot Spot (Getis Ord Gi*) untuk Pemetaan Klaster Industri di Pulau Jawa dengan Memanfaatkan Sistem Informasi Geografi.

Kurniawan, A. \& Sadali, M.I.

signifikasi tinggi secara statistik (hot spots) dan signifikasi rendah secara statistik (cold spots). Metode lokal adalah kuantifikasi autokorelasi spasial dalam wilayah yang lebih kecil dibandingkan global. Metode yang digunakan adalah Getis - Ord Gi statistic dan Local Morans'I atau Local Indicator Spatial Association (LISA). Indeks Moran 's I dapat digunakan dalam pencarian Holspot dengan angka autokorelasi spasial rentang nilai +1 dan -1 . Berbeda dengan metode perhitungan fungsi $\mathrm{Gi}^{*}$ statistik dari Getis dan Ord, nilai autokorelasi spasial dari Gi statislik memiliki rentang +2 dan -2 . Pengolahan nilai pola wilayah dengan indikator autokorelasi spasial dapat menggunakan tools dalam pengolahan data geografi seperti ArcGIS dari ESRI, maupun GeoDa.

Data spasial yang berkembang pesat dan modern memiliki kemampuan untuk visualisasi dan manipulasi di dalam Sistem Informasi Geografi (SIG), mencipiakan permintaan sebuah teknik baru unluk analisis data spasial pada eksplorasi dan sebuah penerimaan (Getis, 1992). Hot spot dalam metode $\mathrm{Gi}^{*}$ statistik adalah sebuah tilik panas, atau kondisi yang mengindikasikan suatu wilayah membentuk clustering atau pengelompokan pada sebuah dislribusi spasial. Hot spot secara sederhana dideteksi dengan cara mengamati suatu lokasi dengan fenomena melimpah/dalam jumlah besar. Prinsip dari metode lokal yang digunakan dalam Getis - Ord Gi statistic adalah menggabungkan nilai observasi dengan lokasi-lokasi sekitar/tetangga untuk mengetahui proses kejadian dari pola spasial dari letak-letak yang diobservasi (membentuk suatu Hotspot).

\subsection{Industri}

Menurut Bintarto (1987) industri adalah bagian dari proses produksi dimana bagian itu tidak mengambil bahan-bahan yang langsung dari alam kemudian diolah menjadi barang-barang yang bernilai dalam masyarakat. Dengan kata lain perkembangan industri dapat diartikan sebagai suatu perubahan suatu organisasi atau kelompok industri tersebut yang semula kecil dalam kurun waktu tertentu berubah menjadi 
Pemanfaatan Analisis Spasial Hot Spot (Getis Ord Gi*) untuk Pemetaan Klaster Industri di Pulau Jawa dengan Memanfaatkan Sistem Informasi Geografi.

Kurniawan, A. \& Sadali, M.I.

sebuah industri yang besar. Sementara dari sudut pandang geografi yang lain, Sumaatmadja (1988) menjelaskan:

"Industri sebagai suatu sistem, merupakan perpaduan subsistem fisis dan subsistem manusia. Subsistem fisis yang mengandung pertumbuhan dan perkembangan industri yaitu komponen-komponen lahan, bahan mentah, atau bahan baku, sumberdaya energi, iklim dengan segala macam proses alamiahnya. Sedangkan subsistem manusia yang mempengaruhi pertumbuhan dan perkembangan industri meliputi komponen-komponen tenaga kerja, kemampuan teknologi, tradisi, keadaan politik, keadaan pemerintahan, transportrasi dan komunikasi, konsumen dan pasar, dan lain sebagainya. Perpaduan semua komponen inilah yang mendukung maju mundurnya suatu industri. Relasi, asosiasi, dan interaksi komponen-komponen tadi dalam suatu ruang, merupakan bidang pengkajian geografi”.

Beberapa penelitian mengenai perkembangan industri, memperlihatkan adanya hubungan yang erat antar perkembangan industri dengan perkembangan struktur ekonomi dan sosial masyarakat yang kemudian mempengaruhi pola pemanfaatan lahan yang merupakan ekspresi dari struktur wilayah atau kota. Perkembangan industri dapat dimaknai sebagai proses bertambahnya pemanfaatan sumberdaya (sumber daya manusia, sumber daya alam, dan sumber daya modal) dalam bidang industri, yang ditandai dengan meningkatnya jumlah industri, bertambahnya lahan industri, bertambahnya sumberdaya manusia yang bergerak di sektor industri serta outcome yang dihasilkan dari industri). Indikator utama tingkat perkembangan industri adalah sumbangan keluaran (output) industri manufaktur dalam Produk Domestik Bruto (Abdullah, 2010).

Sejumlah ahli telah berupaya menetapkan tingkat-tingkat perkembangan ekonomi dan industri. Salah satu teori yang mengulas tentang pertumbuhan ekonomi dan pembangunan (dalam arti proses) dalam beberapa frasa/tahapan yang dikenal dengan terminologi 'less developed, untuk menyebut kondisi suatu negara yang masih mengandalkan sektor tradisional, dan terminologi 'more developed' untuk menyebut kondisi suatu negara yang sudah mencapai tahap 
Pemanfaatan Analisis Spasial Hot Spot (Getis Ord Gi*) untuk Pemetaan Klaster Industri di Pulau Jawa dengan Memanfaatkan Sistem Informasi Geografi.

industrialisasi dengan mengandalkan sektor kapitalis modern. Pembangunan (dalam arti proses), diartikan sebagai modernisasi yakni pergerakan dari masyarakat pertanian berbudaya tradisional ke arah ekonomi yang berfokus pada rasional, industri dan jasa (Sadali, 2013).

Sumaatmadja (1988) memberikan penjelasan mengenai hubungan antara perkembangan industri, kesejahteraan penduduk dan potensi yang perlu dikembangankan dari daerah sekitar.

"Pembangunan industri (industrialisasi) dimaksudkan untuk meningkatkan pendapatan nasional dan kesejahteraan penduduk, juga harus sejalan dengan pemecahan masalah-masalah lainnya dan sedapat mungkin tidak menimbulkan masalah baru yang lebih gawat. Oleh karena itu, baik potensi pengembangan industri maupun masalah yang sedang dialami masyarakat dan negara, harus diteliti sungguh-sungguh. Potensi berbagai daerah dengan segala masalah yang ada pada daerah yang bersangkutan, harus diintegrasikan sebagai suatu upaya yang mensejahterakan masyarakat dan daerah yang bersangkutan".

Kegiatan industri di pedesaan dapat dikembangkan memanfaatkan potensi yang dimiliki oleh desa itu sendiri, baik potensi fisik maupun potensi non fisiknya, jadi berkembangnya suatu industri akan tergantung pada sumber daya alam dan sumber daya manusianya yang ada di desa tersebut. Di samping itu pada dasarnya setiap manusia mempunyai daya adaptasi untuk mempertahankan kelangsungan hidupnya dengan menggunakan kemampuan dan pengetahuan yang dimilikinya, manusia dapat menjadikan sumber daya alam sebagai kekayaan yang dapat mendukung kehidupannya.

Undang-Undang No. 5 Tahun 1984 tentang Perindustrian Pasal 1 menyebutkan bahwa:

1. Perindustrian adalah tatanan dan segala kegiatan yang bertalian dengan kegiatan industri.

2. Industri adalah kegiatan ekonomi yang mengolah bahan mentah, bahan baku, barang setengah jadi, dan/atau barang jadi menjadi barang dengan nilai yang lebih tinggi untuk penggunaannya, termasuk kegiatan rancang bangun dan perekayasaan industri. 
Pemanfaatan Analisis Spasial Hot Spot (Getis Ord Gi*) untuk Pemetaan Klaster Industri di Pulau Jawa dengan Memanfaatkan Sistem Informasi Geografi.

Kurniawan, A. \& Sadali, M.I.

Badan Pusat Statistik Republik Indonesia (2009) mendefinisikan bahwa industri merupakan suatu kegiatan ekonomi yang membutuhkan sumber daya alam (sebagai bahan baku/bahan mentah) maupun sumber daya manusia (sebagai tenaga kerja/pengolah baik menggunakan teknologi atau secara langsung) sehingga menghasilkan suatu produk/barang yang memiliki nilai lebih. Industri merupakan sebuah proses yang melibatkan berbagai macam komponen baik itu komponen yang berasal dari alam maupun komponen yang berasal dari manusia sebagai sumberdaya bagi industri. Dalam proses industri, manusia memiliki peran sebagai penggerak ataupun penentu hasil atau produk yang akan dihasilkan oleh suatu kegiatan ekonomi. Oleh karena itu industri merupakan kegiatan ekonomi yang produktif dan memiliki tujuan sebagai pemenuhan kebutuhan hidup manusia.

Industri menurut Renner (dalam Rachmawaty, 2006) adalah suatu kegiatan manusia di bidang yang produktif. Salah satu kegiatan manusia di bidang ekonomi yang produktif adalah industri manufaktur. Dalam hal ini industri manufaktur adalah suatu aktivitas ekonomi yang membuat bahan baku menjadi batang setengah jadi maupun jadi. Dunia industri terutama industri manufaktur sering digunakan sebagai salah satu penggerak kemajuan, modernisasi dan aktivitas dalam konteks perencanaan tata ruang. Dari definisi tersebut, istilah industri sering disebut sebagai kegiatan manufaktur (manufacturing).

Usaha industri kecil pada umumnya merupakan kegiatan perekonomian keluarga yang mempunyai tenaga kerja 3-5 orang bahkan dapat mencapai 20 tenaga kerja. Sebagaimana pengelompokan industri oleh Badan Pusat Statistik (2009) berdasarkan jumlah tenaga kerja sebagai berikut:

a. Industri besar, jika mempekerjakan 100 orang atau lebih.

b. Insustri sedang, jika mempekerjakan 20-90 orang.

c. Industri kecil, jika mempekerjakan 5-20 orang. 
Pemanfaatan Analisis Spasial Hot Spot (Getis Ord Gi*) untuk Pemetaan Klaster Industri di Pulau Jawa dengan Memanfaatkan Sistem Informasi Geografi.

d. Industri rumah tangga, jika mempekerjakan 3-5 orang (termasuk tenaga kerja yang tidak dibayar).

\section{CARA PENELITIAN}

Penelitian ini menggunakan metode penelitian kuantitatif dengan data sekunder sebagai data utama dan dianalisis secara deskriptif.

\subsection{Lokasi Penelitian}

Daerah yang dipilih untuk penelitian ini sesuai dengan judul yaitu di Pulau Jawa yang terdiri dari 6 Provinsi (Banten, Jawa Barat, Jawa Tengah, Jawa Timur, DKI Jakarta dan Daerah Istimewa Yogyakarta).

\subsection{Bahan atau Materi Penelitian}

Data pokok yang dikumpulkan untuk penelitian ini berupa:

1. Data series jumlah industri di 6 Provinsi (Banten, Jawa Barat, Jawa Tengah, Jawa Timur, DKI Jakarta dan Daerah Istimewa Yogyakarta) dalam 20 tahun terakhir (tahun1993 - 2013).

2. Jenis dan klasifikasi industri di Pulau Jawa (Badan Pusat Statistik).

3. Peta dasar Pulau Jawa (6 Provinsi: Banten, Jawa Barat, Jawa Tengah, Jawa Timur, DKI Jakarta dan Daerah Istimewa Yogyakarta).

4. Data yang berasal dari studi literatur, instansi dan dinas terkait yang dapat memberikan informasi mendukung penelitian ini.

\subsection{Alat}

Alat yang digunakan dalam penelitian ini adalah:

1. Seperangkat komputer

2. Software ArcGIS 9.1. atau versi yang lebih tinggi

3. Software SPSS

4. Software Microsoft Office (terutama Ms. Excell untuk pengolahan data) 
Pemanfaatan Analisis Spasial Hot Spot (Getis Ord Gi*) untuk Pemetaan Klaster Industri di Pulau Jawa dengan Memanfaatkan Sistem Informasi Geografi.

\subsection{Analisis Hasil}

Data yang sudah dikumpulkan di input dan diolah menggunakan software pendukung dalam penelitian ini. Hasil dari pengolahan data disajikan dalam bentuk tabel, grafik, peta atau gambar dan dianalisis secara disktiptif.

\section{A. Penentuan Klaster}

Penentuan klaster industri dailakukan dengan menggunakan Analisis Klaster dan Analisis Spasial Hot Spot (Getis Ord Gi*).

Analisis Klaster

Aglomerasi industri akan menbentuk klaster maupun sentra. Sebaran aglomerasi industri berkaitan erat dalam sebaran industrialisasi. Wilayah yang memiliki pola persebaran terklaster memiliki economic of scale yang lebih besar, sehingga kebutuhan tenaga kerja sektor industri meningkat disekitar lokasi industri. Pola sebaran lokasi industri, menurut Sumaatmadja (1989), dapat dibagi menjadi 3 (tiga) yaitu: (1) pola bergerombol/mengelompok (cluster pattern); (2) pola tersebar tidak merata/acak (random pattern), dan (3) pola tersebar merata (dispersed pattern).

Pola sebaran lokasi industri dapat diukur dengan menggunakan 2 (dua) metode, yakni analisis tetangga terdekat (nearest neighbourhood analysis) dan koefisien asosiasi geografis (KAG). Analisis tetangga terdekat (Bray, 2004) memiliki asumsi sebagai berikut:

1. Wilayah kajian memiliki aksesibilitas yang seragam (tidak ada hambatan),

2. Unit yang diteliti memiliki kekuatan yang sama,

3. Jumlah unit yang diteliti memenuhi persyarakat sampel besar $(n=30)$.

Analisis tetangga terdekat menggunakan jarak antar unit industri sebagai variabel utama dalam pengukuran dan kenampakan titik 
Pemanfaatan Analisis Spasial Hot Spot (Getis Ord Gi*) untuk Pemetaan Klaster Industri di Pulau Jawa dengan Memanfaatkan Sistem Informasi Geografi.

(point features) sebagai unit analisisnya. Rumusnya ialah sebagai berikut:

$\mathrm{R}=2 D \sqrt{\frac{n}{a}} \quad ; \quad \mathrm{D}=\sum \frac{d}{n} \quad$ Rumus 2. Analisis Tetangga Terdekat

Keterangan

R : Nearest Neighbour Index

D : Rata-rata jarak antar titik terdekat

d : Jarak antar titik terdekat

$\mathrm{n}$ : Jumlah unit

A : Luas wilayah

Klasifikasi nilai $\mathrm{R}$ ialah:

a. Nilai $R<1,00$; berarti mengelompok (cluster pattern)

b. Nilai $R=1,00$; berarti tersebar (random distribution pattern)

c. Nilai $R>1,00$; berarti tidak berpola (un organized pattern).

$>$ Analisis Spasial Hot Spot (Getis Ord Gi*)

Adapun formulasi yang digunakan untuk nilai Getis Ord $\mathrm{Gi}^{\star}$ dapat dilihat pada Rumus 1 pada Sub Bab Tinjauan Pustaka di atas.

\section{B. Klasifikasi Industri}

Klasifikasi industri mengacu pada ketentuan yang telah ditetapkan atau diatur oleh lembaga negara seperti Badan Pusat Statistik. Klasifikasi industri dalam penelitian ini dapat dibagi berdasarkan skala dan jumlah tenaga kerja. Klasifikasi industri mengacu dari Badan Pusat Statistik (2009) berdasarkan jumlah tenaga kerja sebagai berikut:

a. Industri besar, jika mempekerjakan 100 orang atau lebih.

b. Industri sedang, jika mempekerjakan 20-90 orang.

c. Industri kecil, jika mempekerjakan 5-20 orang.

d. Industri rumah tangga, jika mempekerjakan 3-5 orang (termasuk tenaga kerja yang tidak dibayar). 
Pemanfaatan Analisis Spasial Hot Spot (Getis Ord Gi*) untuk Pemetaan Klaster Industri di Pulau Jawa dengan Memanfaatkan Sistem Informasi Geografi.

Kurniawan, A. \& Sadali, M.I.

Disperindag melakukan klasifikasi industri menurut skala usaha berdasarkan jumlah modal dibagi menjadi tiga:

a. Industri Besar adalah perusahaan dengan investasi lebih dari Rp. 600 juta,

b. Industri Menengah adalah perusahaan dengan investasi antara $\mathrm{Rp}$ 100-600 juta,

c. Industri Kecil adalah perusahaan dengan investasi kurang dari Rp. 100 juta. 
Pemanfaatan Analisis Spasial Hot Spot (Getis Ord Gi*) untuk Pemetaan Klaster Industri di Pulau Jawa dengan Memanfaatkan Sistem Informasi Geografi.

Kurniawan, A. \& Sadali, M.I.

\section{DAFTAR PUSTAKA}

Abdullah. 2010. Pengaruh Perkembangan Industri Terhadap Pola Pemanfaatan Lahan di Wilayah Kecamatan Bergas Kabupaten Semarang. Tesis. Semarang: Universitas Diponegoro.

Anselin, L. (1995). Local Indicators of Spatial Association - LISA. Geographical Analysis, Vol. 27, 93-115.

Asosiasi Klaster Indonesia (AKsl). 2014. Pengertian Klaster. Bersumber dari http://asosiasiklasterindonesia.com. Diakses tanggal 19 Januari 2014.

Badan Pusat Statistik Republik Indonesia. 2009. Konsep Industri. http://www.bps.go.id. Jakarta: Badan Pusat Statistik. Diunduh pada tanggal 29 Maret 2012.

Bintarto, R.. 1987. Pengantar Geografi Kota. Yogyakarta: Spring.

David A.w. 2004. Clusters from the Inside and Out: Lessons from the Canadian Study of Cluster Development. Urban Studies, May 2004.

Departemen Perindustrian RI. 2005. Peraturan Menteri Perindustrian Nomor 04/M-IND/PER/4/2005 Tahun 2005 tentang Pedoman Umum Pembangunan Industri dengan Pendekatan Klaster. Departemen Perindustrian RI. Jakarta.

Desrochers dan Sautet. 2004. Cluster Based Economic Strategy, Fasilitation Policy and The Market Process, The Review og Austrian Economics, 2004, Vol. 17. P. $233-245$.

Fujita, M. and Thisse, J.F. 1986. Spatial Competition with a Land Market: Hotelling and von Thunen Unified. Rev. Econ. Stud. 53, 819-841.

Getis, A. and Ord, J.K. 1992. The Analysis of Spatial Association by Use of Distance Statistics. Geographical Analysis, Vol. 24, No. 3 (July 1992). Ohio State University Press.

Getis, Arthur. 2008. A History of the Concept of Spatial Autocorrelation: A Geographer's Perspective. Geographical Analysis, Vol. 40, 297-309.

JICA. 2004. The Study on Strengthening of SME Cluster in Indonesia. Final Report. JICA and Republik of Indonesia Ministry of Industry for Economic Affairs. Jakarta.

Kuncoro, M.. 2002. Analisis Spasial dan Regional: Studi Aglomerasi dan Kluster Industri Indonesia. UPP AMP YKPN. Yogyakarta.

Kurniawan, A. 2013. Model Prediksi Keberlanjutan Pembangunan Berdasarkan Daya Dukung Wilayah di Provinsi Daerah Istimewa Yogyakarta. Disertasi. Fakultas Geografi UGM. Yogyakarta.

Munnich, Jr., Schrock, G., Cook, K. 2002. Rural Knowledge Clusters: The Challenge of Rural Economic Prosperity. Reviews of Economic Development Literature and Practice: No. 12 . University of Minnesota. 
Pemanfaatan Analisis Spasial Hot Spot (Getis Ord Gi*) untuk Pemetaan Klaster Industri di Pulau Jawa dengan Memanfaatkan Sistem Informasi Geografi.

Porter, ME. 1990. Competitive Advantage of Nations. Free Press. New York.

Rachmawaty, Andi. 2006. Dampak Perkembangan Industri Logam terhadap Kondisi Sosial Ekonomi Masyarakat Pelaku Industri Tahun 19952005 (Kasus di Kecamatan Adiwerna, Kabupaten Tegal). Tesis. Yogyakarta: Universitas Gadjah Mada.

Sadali, M. I. 2013. Pola Mobilitas dan Distribusi Spasial Pekerja Pada Kawasan Industri Piyungan, Kabupaten Bantul. Yogyakarta: Fakultas Geografi UGM.

Sumaatmadja, Nursid. 1988. Studi Geografi: Suatu Pendekatan dan Analisa Keruangan. Bandung: Alumni.

Taufik, T.A. 2008. Klaster Industri: Diskusi Pengembangan Klaster Indonesia. Bersumber dari http://klasterindustri.blogspot.com/2008/12/apa-itu-klaster-industri.html. Diakses tanggal 19 Januari 2014.

Weijland, H. 1999. 'Microenterprise Clusters in Rural Indonesia: Industrial Seedbed and Policy Target', World Development, 27(9):1515-30. 